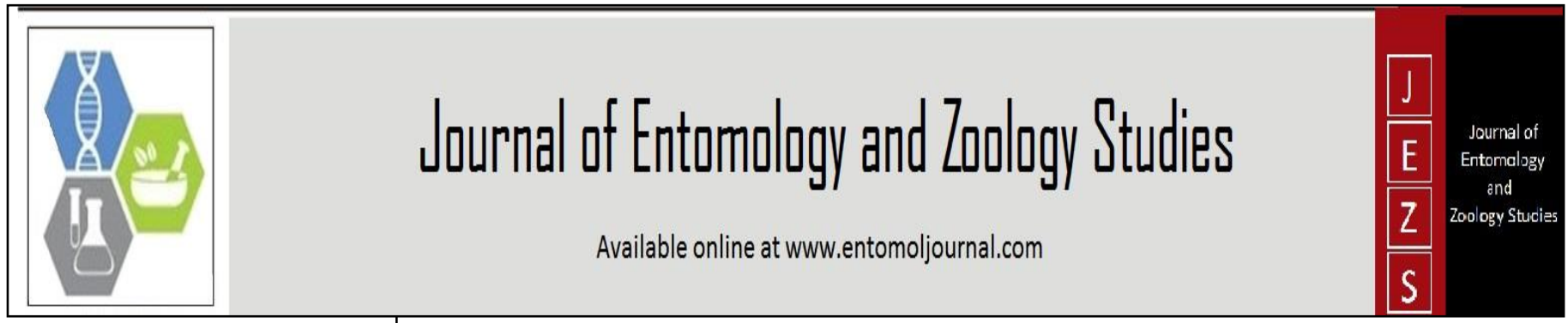

E-ISSN: 2320-7078

P-ISSN: 2349-6800

www.entomoljournal.com

JEZS 2021; 9(1): 47-51

(C) $2021 \mathrm{JEZS}$

Received: 25-11-2020

Accepted: 27-12-2020

Jean Victor Nery da Silva

Department of Biologica

Sciences, Instituto Federal de

Educação, Ciência e Tecnologia

do Paraná, IFPR-Campus

Umuarama, Umuarama, Paraná,

Brazil

Alex Sandro Barros de Souza

Department of Biological

Sciences, Instituto Federal de

Educação, Ciência e Tecnologia

do Paraná, IFPR-Campus

Umuarama, Umuarama, Paraná,

Brazil

Giuliano Kaulfuss Bertinoti

Department of Biological

Sciences, Instituto Federal de

Educação, Ciência e Tecnologia

do Paraná, IFPR-Campus

Umuarama, Umuarama, Paraná,

Brazil

Patrícia Pereira Gomes

Department of Biological

Sciences, Instituto Federal de

Educação, Ciência e Tecnologia

do Paraná, IFPR-Campus

Umuarama, Umuarama, Paraná,

Brazil

José Adolfo Mota de Almeida

Department of Biological

Sciences, Instituto Federal de

Educação, Ciência e Tecnologia

do Paraná, IFPR-Campus

Umuarama, Umuarama, Paraná,

Brazil

Marcos Magalhães de Souza

Department of Biological

Sciences, Instituto Federal de

Educação, Ciência e Tecnologia

do Paraná, IFPR-Campus

Umuarama, Umuarama, Paraná,

Brazil

Corresponding Author:

Jean Victor Nery da Silva

Department of Biological

Sciences, Instituto Federal de

Educação, Ciência e Tecnologia

do Paraná, IFPR-Campus

Umuarama, Umuarama, Paraná,

Brazil

\section{Social wasps fauna (Vespidae) of semideciduous seasonal forest in southern Brazil}

\author{
Jean Victor Nery da Silva, Alex Sandro Barros de Souza, Giuliano \\ Kaulfuss Bertinoti, Patrícia Pereira Gomes, José Adolfo Mota de Almeida \\ and Marcos Magalhães de Souza
}

DOI: $\underline{\text { https://doi.org/10.22271/j.ento.2021.v9.i1a.8208 }}$

\begin{abstract}
Social wasps are insects that perform numerous environmental services, with emphasis on pollination and predation of agricultural pests. However, despite the increase in efforts to know the social wasps geographical distribution and richness, there are still many areas and ecosystems with few studies of this nature, such as the Paraná State, Southern Brazil. To collaborate with these efforts, this work aimed to carry out an inventory of social wasps in semideciduous forest in the Ilha Grande National Park, an integral conservation unit in the Paraná State. The Sampling took place from February to November 2019, totalizing 15 days and 60 hours, being carried out on six islands of the Paraná River, using the active search for species and colonies records. Fourteen species were registered, distributed in six genera. The study revealed a low species richness, which may be related to the area's usage history, as well as to other factors. This highlights the need for greater sampling efforts in other areas of this conservation unit.
\end{abstract}

Keywords: Atlantic forest, Mischocytttarus, Polistes, Polistinae, Polybia

\section{Introduction}

Social wasps are insects of the Hymenoptera order, Vespidae family, which is formed by six subfamilies, three of which are solitary (Euparigiinae, Eumeninae and Massarinae) and the other three eusocial (Stenogastrinae, Vespinae and Polistinae) ${ }^{[1]}$. Polistinae, with a cosmopolitan distribution and wide representation in the tropical region, is the only eusocial subfamily occurring in Brazil, being divided into three tribes (Mischocyttarini, Epiponini and Polistini), which encompasses 26 genera ${ }^{[1,2]}$.

These insects perform various environmental services, such as predation of agricultural pests ${ }^{[1,3,4]}$ and pollination, also acting as bioindicators of riparian forest conservation ${ }^{[5]}$. However, the natural environments changing, such as forest fragmentation, are negatively affecting their communities ${ }^{[6,7]}$.

In Brazil, these environmental changes have been frequent in different biomes, and as a result, there is an increase in studies aimed at knowing the social wasps geographical distribution and richness, due to their importance in ecosystems ${ }^{[8,9]}$. However, there are locations in the country where these studies are still scarce. In Paraná State, for example, the only records come from material deposited in biological collections ${ }^{[10]}$ and a recent review study that counted 23 species for the state ${ }^{[9]}$.

In this state, the semideciduous seasonal forest, phytophysiognomy of the Atlantic Forest domain ${ }^{[11]}$, occurs in the West, Northwest and North, being characterized by leaves loss of about $50 \%$ of the tree species in the winter period. In Brazil, the literature reports social wasps inventories in seasonal semideciduous forests in different states such as: São Paulo [12, 13, 14], Minas Gerais ${ }^{[8,15,16,17]}$ and Mato Grosso do Sul ${ }^{[18]}$.

To contribute to the knowledge about this type of forest formation, the present work aimed to present the social wasps inventory from the semideciduous forest of the Paraná State, inserted in an integral conservation unit, the Ilha Grande National Park.

\section{Materials and Methods}

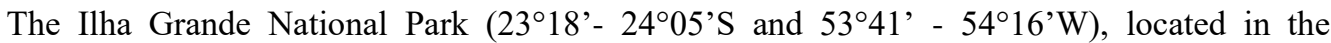
northwest of Paraná State, it borders with Mato Grosso do Sul State. 
It belongs to the last stretch of Paraná River free of dams, which in turn makes up a complex of islands, islets and floodplains. It has phytophysiognomy of semideciduous seasonal forest and ombrophilous forest, belonging to the Atlantic Forest domain ${ }^{[19]}$.

Studies estimate that in the last century the state's forest coverage corresponded to $83.41 \%$ of its territory [20]. However, these forests were losing space for different human activities, with emphasis on intensive agriculture and livestock. In the specific case of the semideciduous seasonal forest, there was a complete mischaracterization due to the advance of areas with secondary vegetation, so that, currently, it is estimated that less than $5 \%$ of its total area remains ${ }^{[21]}$. The study, authorized by ICMBio through the license SISBIO 65047-1, was carried out during three collection campaigns carried out on three islands and three islets (Fig. 1), between February and November 2019, from 8 am to 5 pm, totalizing 15 days and 60 hours of sampling. The specimens were collected through an active search, using an entomological net, and once captured, the individuals were stored in $70 \%$ alcohol. Social wasp richness was not measured for each island, but for the entire area, since the islands comparison have not been the object of this study.

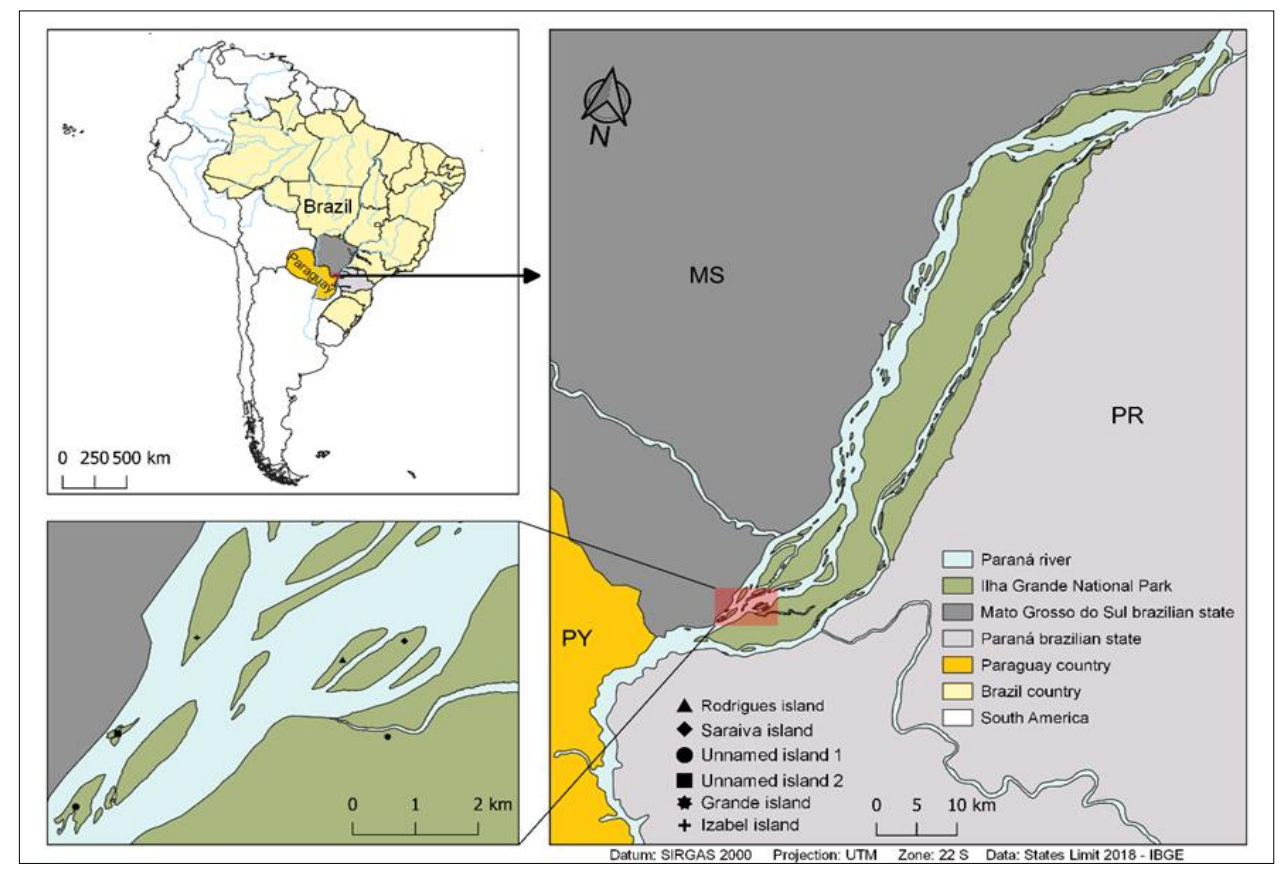

Fig 1: Location of the islands where social wasps were collected in the Ilha Grande National Park, Paraná, southern Brazil. Qgis 3.10.2.

The material was screened, assembled and identified at the IFSULDEMINAS Zoology Laboratory, Campus Inconfidentes, Minas Gerais State. Complex identification species were sent to the Dr. Orlando Tobias da Silveira, Emílio Goeldi Museum, Belém, Pará State, for taxonomic confirmation. The material identified by the taxonomist Dr. Orlando Tobias Silveira is deposited in the social wasps collection of the Emílio Goeldi Museum.

\section{Results and Discussions}

In this study, 14 species were registered, distributed in six genera (Table 1), with Mischoctttarus (de Saussure) presenting greater richness (4). This genus comprises 253 described species, with cumulative distribution extending from southeastern Canada to northern Argentina [1, 22, 23]. In Brazil, about 124 species have been registered ${ }^{[22,23]}$, and the record of new occurrences is still common in ecosystems and states [24, 25]. This is due to the large number of species included in the genus and the fact that many environments and locations have not yet been sampled, even in areas of the Atlantic Forest, the best inventoried Brazilian biome ${ }^{[9]}$.

Table 1: List of social wasp species from Ilha Grande National Park, PR

\begin{tabular}{|c|c|}
\hline Tribo & Espécie \\
\hline \multirow{5}{*}{ Mischocyttarini } & Mischocyttarus cerberus (Richards, 1940) \\
\hline & Mischocyttarus drewseni Saussure, 1857 \\
\hline & Mischocyttarus rotundicollis (Cameron, 1912) \\
\hline & Mischocyttarus frontalis (Fox, 1898) \\
\hline & Mischocyttarus cassununga (R. von Ihering, 1903) \\
\hline \multirow[t]{2}{*}{ Polistini } & Polistes simillimus Zikán, 1951 \\
\hline & Polistes versicolor (Olivier, 1791) \\
\hline \multirow{7}{*}{ Epiponini } & Apoica gelida Van der Vecht, 1973 \\
\hline & Brachygastra lecheguana (Latreille, 1824) \\
\hline & Brachygastra augusti (de Saussure, 1854) \\
\hline & Polybia occidentalis (Olivier,1791) \\
\hline & Polybia paulista $\mathrm{H}$. von Ihering 1896 \\
\hline & Polybia sericea (Olivier, 1791) \\
\hline & Protopolybia exigua_(de Saussure, 1854) \\
\hline
\end{tabular}


Despite this, the number of Mischocyttarus species observed in the present study was low, since the genus usually stands out in inventories $[6,26]$. This may be a reflection of species having small and cryptic colonies, which makes their registration difficult [27], especially in a dense forest environment as in the areas of the present study, a type of environment that makes it difficult to register colonies for all wasp genera, which may explain the results obtained ${ }^{[26]}$.

The species registered in this study are widely distributed in Brazil [10], such us: Brachygastra lecheguana that occurs in Cerrado areas in the states of Mato Grosso [28], Mato Grosso do Sul ${ }^{[29]}$ and in Minas Gerais ${ }^{[30]}$, being that, in this last one, the species also occurs in deciduous forest ${ }^{[31]}$; Mischocyttarus cerberus that occurs in Caatinga in the Ceará State ${ }^{[32]}$ and agricultural areas associated with semideciduous forest in Minas Gerais ${ }^{[33]}$. On the other hand, Mischocyttarus frontalis has record only in perennial forests in Minas Gerais State [26] and in the states of Goiás and Mato Grosso ${ }^{[10]}$.

Regarding the richness of social wasp species, similar results were observed by Souza et al. (2017) [34], in other semideciduous seasonal forest environments, where the richness varied from 13 to 45 species. However, the lowest values ( $n=13$ and $n=19$ ) were recorded, respectively, in studies carried out in agricultural systems within forested areas ${ }^{[33,35]}$. These results are similar to those observed in the present study, whose sampled islands have a history of anthropic occupation, and are still in the process of regeneration ${ }^{[36]}$.

Studies with social wasps carried out on similar phytophysiognomies, registered a greater number of species ${ }^{[8,}$ $15,17,27$. Greater social wasps richness seems to be related to environments with greater vegetation structural complexity, where there is greater food resources availability, as well as better temperature and air humidity conditions, which favors the establishment and survival of these insects ${ }^{[34,37]}$.

Another situation that indicates the forest regeneration process of the islands under study, and their condition still impacted, is the fact that different social wasp species were collected in expropriated and abandoned buildings within the Ilha Grande National Park. This shows synanthropy signs in these species, as it is the case of Mischocyttarus cassununga, M. drewseni, Polistes simillimus and P. versicolor, situation already reported by other authors ${ }^{[38,39]}$, forming a group of common species with wide geographical distribution. This may be due to the urbanization pressure on natural environments and because human constructions can act as a shelter against weather, besides reducing competition for nesting substrates with other species ${ }^{[40]}$.

Still in relation to the low species richness, this may be related to the sampling method. In this study, the active search was used, which although it is considered the most efficient method for sampling social wasps ${ }^{[15]}$, its use is less efficient in forest environments, such as in the studied islands, where the denser vegetation makes it difficult to register colonies and individuals. In these environments, it is suggested to use malaise-type flight intercepting traps ${ }^{[41]}$.

The size of the sampled area must also be considered, since during the collection period only about $0.11 \%$ of the total area of the park was sampled. Thus, increasing the sampling effort and the adoption of attractive traps may increase the social wasp species number found in the Ilha Grande National Park, and consequently, the number of records in the Paraná State. Analyzing the Paraguayan fauna, from the guide of GarceteBarrett (1999) ${ }^{[42]}$ and the new records of Garcete-Barrett
(2001) [43], specifically for species registered in phytophysiognomies similar to the Ilha Grande National Park, it is evident that a large number of species are shared with those observed in studies carried out in Brazil. This indicates that with an increase in the sampling effort and / or an increase in the collection area, possibly the species $M$. paraguayensis; $P$. lanio lanio and $P$. platycephala sylvestris, will also be recorded in the Paraná State.

The survey of social wasps is essential to verify the local diversity and its distribution in different environments ${ }^{[44]}$. In addition, these hymenoptera species have great relevance in the maintenance of food chains, both in agricultural systems and in natural environments ${ }^{[45,46]}$. Therefore, studies carried out with wasps can be fundamental for the efficient implementation of conservation methods, as well as for the orderly use of environmental resources ${ }^{[5]}$.

\section{Conclusion}

In summary, this study provides a social wasps inventory from the semideciduous forest of the Paraná State, inserted in the Ilha Grande National Park, which is essential for implementing preservation and recovery measures for this conservation unit. However, further studies and greater sampling effort are suggested in this park, which can result in an increase in the number of social wasp species registered as well as increasing knowledge of its diversity and distribution.

\section{Acknowledgements}

We thank to Dr. Orlando Tobias Silveira (Emílio Goeldi Museum) for the identification of social wasp species. To ICMBio for the research permits (SISBIO $\mathrm{n}^{\mathrm{o}}$ 65047-1). To environmental analysts and brigade members of ICMBio for their assistance in the collecting logistics in the Ilha Grande National Park, Paraná State. To IFSUDEMINAS Zoology Laboratory, Campus Inconfidentes. To members of the field team who assisted in data collection (Diego Santiago, Mariane Peczek).

\section{References}

1. Carpenter JM, Marques OM. Contribuição ao Estudo dos Vespídeos do Brasil. Série Publicações Digitais, Departamento de Fitotecnia, Salvador 2001, CD3.

2. Prezoto F, Júnior CR, Oliveira SA, Elisei T. Manejo de vespas e marimbondos em ambiente urbano. In: Pinto AS, Rossi MM, Salmeron E (eds.) Manejo de Pragas Urbanas. Piracicaba 2007, 123-126.

3. Picanço MC, Oliveira IR, Rosado JF, Silva RS. Natural Biological Control of Ascia monuste by the Social Wasp Polybia ignobilis (Hymenoptera: Vespidae). Sociobiology 2010;56(1):67-76.

4. Prezoto F, Maciel TT, Detoni M, Mayorquin AZ, Barbosa BC. Pest Control Potential of Social Wasps in Small Farms and Urban Gardens. Insects 2019;10(1):110 .

5. Souza MM, Louzada J, Serrão JE, Zanuncio JC. Social wasps (Hymenoptera: Vespidae) as indicators of conservation degree of riparian forests in south east Brazil. Sociobiology 2010;56(1):1-10.

6. Bueno ET, Souza MM, Clemente MA. The Effect of Forest Fragmentation on Polistinae. Sociobiology 2019;66(1):508-514.

7. Graça MB, Somavilla A. Effects of forest fragmentation on community patterns of social wasps (Hymenoptera: Vespidae) in Central Amazon. Austral Entomology 
2018;58(1):657-665.

8. Barbosa BC, Detoni M, Maciel TT, Prezoto F. Studies of social wasp diversity in Brazil: Over 30 years of research, advancements and priorities. Sociobiology 2016a;63(1):858-880.

9. Souza MM, Guedes GT, Milani LR, Souza ASB, Gomes PP. Social Wasps (Vespidae: Polistinae) from the Brazilian Atlantic Forest. Sociobiology 2020;67(1):0112.

10. Richards OW. British Museum (Natural History), London 1978, 1-580.

11. Oliveira-Filho AT. Definição e delimitação de domínios e subdomínios das paisagens naturais do estado de Minas Gerais. In: Scolforo JR, Carvalho LMT. Mapeamento e Inventário da Flora e dos Reflorestamentos de Minas Gerais. UFLA, Lavras 2006, 21-35.

12. Gomes B, Noll FB. Diversidade de vespas sociais (Hymenoptera: Vespidae; Polistinae) em três fragmentos de floresta estacional semidecidual no Noroeste do estado de São Paulo, Brasil. Revista Brasileira de Entomologia 2009;53(1):428-431.

13. Lima ACO, Castilho-Noll MSM, Gomes B, Noll FB. Social wasp diversity (Vespidae, Polistinae) in a forest fragment in the Northeast of São Paulo state sampled with different methodologies. Sociobiology 2010;55(1):613-626.

14. Tanaka-Junior GM, Noll FB. Diversity of social wasps on semideciduous seasonal forest fragments with different surrounding matrix in Brazil. Psyche: A Journal of Entomology 2011;1(1):1-8.

15. Souza MM, Prezoto F. Diversity of social wasps (Hymenoptera, Vespidae) in Semideciduous forest and cerrado (savanna) regions in Brazil. Sociobiology 2006;4(1):135-147.

16. Jacques GC, Castro AA, Souza GK, Silva-Filho R, Souza MM, Zanuncio JC. Diversity of social wasps in the Campus of the Universidade Federal de Viçosa in Viçosa, Minas Gerais State, Brazil. Sociobiology 2012;59(1):1053-1062.

17. Albuquerque CHB, Souza MM, Clemente MA. Comunidade de vespas sociais (Hymenoptera, Vespidae) em diferentes gradientes altitudinais no sul do estado de Minas Gerais, Brasil. Biotemas 2015;28(1):131-138.

18. Bonfim MGCP, Antonialli-Junior WF. Community structure of social wasps (Hymenoptera: Vespidae) in riparian forest in Batayporã, Mato Grosso do Sul, Brazil. Sociobiology 2012;59(1):755-765.

19. Svolenski AC. Plano de Manejo do Parque Nacional de Ilha Grande: Contextualização da Unidade de Conservação, ICMBio, Curitiba 2019.

20. Souza MC, Monteiro R. Levantamento florístico em remanescente de floresta ripária no alto rio Paraná: Mata do Araldo, Porto Rico, Paraná, Brasil. Acta Scientiarum. Biological Sciences 2005;27(1):405-414.

21. Mikich SB, Silva SM. Composição florística e fenologia das espécies zoocóricas de remanescentes de floresta estacional semidecidual no centro-oeste do Paraná, Brasil. Acta Botanica Brasilica 2001;15(1):89-113.

22. Borges RC, Silveira OT. Revision of the species-group of Mischocyttarus (Omega) filiformis (de Saussure 1854), with description of three new species (Hymenoptera, Vespidae). Zootaxa 2019;4657(3):545-564.

23. Silveira OT. Phylogeny of wasps of the Genus Mischocyttarus de Saussure (Hymenoptera, Vespidae,
Polistinae). Revista Brasileira de Entomologia 2008;54(1):510-549.

24. Prezoto F, Souza MM, Elpino-Campos A, Del-Claro K. New records of social wasps (Hymenoptera, Vespidae) in the Brazilian Tropical Savanna. Sociobiology 2009;54(1):01-06.

25. Souza MM, Pires EP, Eugênio R, Silva-Filho R. New Occurrences of Social Wasps (Hymenoptera: Vespidae) in Semideciduous Seasonal Montane Forest and Tropical Dry Forest in Minas Gerais and in the Atlantic Forest in the State of Rio de Janeiro. Entomo Brasilis 2015a;8(1):65-68.

26. Souza MM, Pires EP, Ferreira M, Ladeira TE, Pereira M, Elpino-Campos A et al. Biodiversidade de vespas sociais (Hymenoptera: Vespidae) do Parque Estadual do Rio Doce, Minas Gerais, Brasil. Biota 2012;5(1):04-19.

27. Souza MM, Pires EP, Silva-filho R, Ladeira TE. Community of social wasps (Hymenoptera: Vespidae) in areas of Semideciduous Seasonal Montane Forest. Sociobiology 2015b;62(1):598-603.

28. Diniz IR, Kitayama K. Seasonality of vespid species (Hymenoptera: Vespidae) in a central Brazilian cerrado. Revista de Biologia Tropical 1998;46(1):109-114.

29. Auko TH, Carbonari V, Ribeiro DG, Silvestre R. Checklist of wasp (Hymenoptera, Vespidae) from Mato Grosso do Sul, Brazil. Iheringia Série Zoologia 2017;107(Extra):1-7.

30. Elpino-Campos A, Del-Claro K, Prezoto F. Diversity of Social Wasps (Hymenoptera, Vespidae) in the Cerrados of Uberlândia, Minas Gerais State, Brazil. Neotropical Entomology 2007;36(1):685-692.

31. Brunismann AG, Souza MM, Pires EP, Coelho EL, Milani LR. Social wasps (Hymenoptera: Vespidae) in deciduous seasonal forest in Southeastern Brazil. Journal of Entomology and Zoology Studies 2016;4(4):447-452.

32. Somavilla A, Oliveira ML, Rafae JA. Social Wasps (Vespidae: Polistinae) from Two National Parks of the Caatinga Biome, in Brazil. Sociobiology 2017;64(1):334338.

33. Freitas JL, Pires EP, Oliveira TTC, Santos NL, Souza MM. Vespas sociais (Hymenoptera: Vespidae) em lavouras de Coffea arabica L. (Rubiaceae) no Sul de Minas Gerais. Revista Agrogeoambiental 2015;7(1):6777.

34. Souza MM, Brunismann AG, Clemente MA. Social wasp richness and species distributions among ecosystem types in Minas Gerais, Brazil. Sociobiology 2017;64(1):456465.

35. Auad AM, Carvalho CA, Clemente MA, Prezoto F. Diversity of social wasps in a silvipastoral system. Sociobiology 2010;55(1):627-636.

36. Godoy AMG. Aspectos socioeconômicos da região de ilha grande. In: Campos JB (ed.) Parque Nacional de Ilha Grande: re-conquista e desafios. Iap - Instituto Ambiental do Paraná, Maringá 2001, 1-118.

37. Santos GMM, Bichara FCC, Resende JJ, Cruz JD, Marques OM. Diversity and community structure of social wasps (Hymenoptera: Vespidae) in three ecosystems in Itaparica island, Bahia State, Brazil. Neotropical Entomology 2007;36(1):180-185.

38. Castro MM, Avelar DLG, Souza AR, Prezoto F. Nesting substrata, colony success and productivity of the wasp Mischocyttarus cassununga. Revista Brasileira de Entomologia 2014;58(2):168-172. 
39. Oliveira TCC, Souza MM, Pires EP. Nesting habits of social wasps (Hymenoptera: Vespidae) in forest fragments associated with anthropic areas in southeastern Brazil. Sociobiology 2017;64(1):101-104.

40. Lima MAP, Lima JR, Prezoto F. Levantamento dos gêneros, flutuação das colônias e hábitos de nidificação de vespas sociais (Hymenoptera, Vespidae), no campus da UFJF, Juiz de Fora, MG. Revista Brasileira de Zoociências 2000;2(1):69-80.

41. Somavilla A, Morais-Junior RNM, Rafael JA. Is the social wasp fauna in the tree canopy different from the understory? Study of a particular area in the Brazilian Amazon Rainforest. Sociobiolgy 2019;66(1):179-185.

42. Garcete-Barrett BR. Guía ilustrada de las avispas sociales del Paraguay. The Natural History Museum, London 1999, 1-43.

43. Garcete-Barrett BR. Seis nuevos registros de avispas sociales para el Paraguay (Hymenoptera: Vespidae: Polistinae). Boletim del Museo Nacional de Historia Natural de Paraguay 2001;13(1):46-49.

44. Cerqueira RJ, Andena SR. Levantamento da fauna de vespas (Hymenoptera, Vespidae, Polistinae) na região do Arraial do Retiro, distrito de Coração de Maria, Bahia. Anais Seminário de Iniciação Científica 2017;1(1):1-4.

45. Elisei T, Ribeiro-Junior C, Fernandes-Junior AJ, Vaz-eNunes J, De-Souza AR, Prezoto F. Management of Social Wasp Colonies in Eucalyptus Plantations (Hymenoptera: Vespidae). Sociobiology 2012;59(4):1-8.

46. Milani LR, Jacques GC, Clemente MA, Coelho EL, Souza MM. Influências dos fragmentos florestais sobre a nidificação de vespas sociais (Hymenoptera, Vespidae) em cafeeiro. Revista Brasileira de Zoociências 2020;21(1):1-12. 